\title{
The Kadro journal on the agrarian question in Turkey in the 1930s
}

\author{
ERdEM ÖZGÜr AND AlP YÜCEL KaYA
}

KEYWORDS: Kadro Movement, agrarian question, land reform, Turkey.

JEL CODES: B24, B31, N54, Q15.

smail Hüsrev Tökin, in his preface to Türkiye Köy İktisadiyat1 (1990 [1934]), ar-
gues that an economist who might travel Turkey from its western to eastern fron-
tiers would face diverse social and economic scenes: remnants from the previous centuries, in both their mature and embryonic forms. A common point of view of the literature related to agrarian question, from Kautsky to Chayanov, was the problem of the co-existence of pre-capitalist and capitalist agricultural structures within the context of a capitalist economic system, and the political implications of this setting. Tökin's discussion was a part of such literature in general but it was also part of a movement formed around a monthly journal, Kadro, published between 1932 and 1935. This shortlived movement succeeded in producing original ideas with a dependency-like, developmentalist approach. Our paper aims to explain the analysis of Tökin, and also the Kadro journal on "the agrarian question" in Turkey. To this end, it will discuss how their empirical observations on agrarian dynamics in Turkey in the 1930s, and their theoretical background on the agrarian question, interacted to examine the specific aspects of Turkey's rural economy. It concludes that Kadro authors'focus in the agrarian question was on the problem of accumulation for industrialization, rather than the problem of democratic or socialist struggle. 


\section{La cuestión agraria en Turquía en la revista Kadro en la década de 1930}

\section{PALABRAS CLAVE: movimiento Kadro, cuestión agraria, reforma agraria, Turquía.}

\section{CÓDIGOS JEL: B24, B31, N54, Q15.}

Smail Hüsrev Tökin, en su prólogo a Türkiye Köy İktisadiyatı (1990 [1934]), se-
ñaló que un economista que viajara por Turquía desde sus fronteras occidentales
a las orientales encontraría entornos sociales y económicos diversos que analizó en su libro: vestigios de los siglos anteriores, tanto en sus formas embriónicas como maduras, en otras palabras señoríos feudales; grandes aparcerías; explotaciones capitalistas; y, pequeñas explotaciones campesinas. Un tema común en la literatura sobre la cuestión agraria, desde Kautsky a Alexander Chayanov, fue el problema de la coexistencia de estructuras agrarias precapitalistas y capitalistas en el contexto de un sistema económico capitalista, y sus implicaciones políticas. El trabajo de Tökin puede insertarse en general en este tipo de literatura pero fue también parte de un movimiento formado alrededor de una revista mensual, Kadro, publicada entre enero de 1932 y enero de 1935. Este movimiento de corta duración fue exitoso en generar ideas originales con un enfoque desarrollista del tipo de la teoría de la dependencia. Este artículo se propone ayudar a explicar el análisis de Tökin, en particular, y la revista Kadro en general, sobre la "cuestión agraria» en Turquía. Para ello, se discutirá cómo interactuaron sus observaciones empíricas sobre las dinámicas agrarias en Turquía en la década de los treinta del siglo XX y sus planteamientos teóricos sobre la cuestión agraria, para examinar aspectos específicos de la economía rural turca. Se concluye que el principal foco de los autores de Kadro sobre la cuestión agraria estuvo más en la problemática de la acumulación que en los aspectos productivos y políticos.

Received: 2015-10-13 - Revised: 2017-03-15 - Accepted: 2017-05-22

Erdem Özgür [orcid.orgl 0000-0002-0324-011X] is Professor of Economics at the Faculty of Business, Dokuz Eylül University. Address: Dokuz Eylül Üniversitesi İşletme Fakültesi İktisat Bölümü Kaynaklar Yerleşkesi, 35160 İmir (Turkey).E-mail:erdem.ozgur@deu.edu.tr

Alp Yücel Kaya [orcid.org/ 0000-0003-2055-5073] is Professor of Economics at the Faculty of Administrative and Economic Sciences, Ege University. Address: Ege Üniversitesi İ̈BF İktisat Bölümü Bornova, 35100 İzir (Turkey).E-mail: alp.yucel.kaya@ege.edu.tr 


\section{INTRODUCTION}

İsmail Hüsrev Tökin, in his preface to "The Rural Economy of Turkey" (Türkiye Köy Iktisadiyatr), published in 1934, argues that an economist who might travel Turkey from its western to eastern frontiers would face diverse social and economic scenes: feudal manors, large sharecropping farms, capitalist farms and small peasant farms. The analysis of Tökin follows that of literature on the agrarfrage problematizing dynamics of agricultural structures within the context of a capitalist economic system, and the political implications of this setting. Tökin's discussion was very much part of such literature in general but it was also part of a movement formed around a monthly journal, Kadro, published between January 1932 and January 1935. The authors of this journal, who will be presented briefly in the next section, formed a political movement as they worked closely together to achieve common economic and political goals. Their ideas and policy proposals were influential back then as they have been since. Although this short-lived movement was a product of an uncertain period in both national and international spheres, it succeeded in producing original ideas, such as a dependency-like, developmentalist approach based on the centrality of core-periphery conflict in economic history. Thanks to their methodological framework, forged in the journal, their empirical research on the economic dynamics of Turkey in the 1930s allowed Tökin and others to develop a certain theoretical approach.

Kadro has sparked numerous publications since its own publication ${ }^{1}$. The aim of this study is to present the Kadro authors' views on the agrarian question in Turkey, which locate economic development in the context of national liberation movements within the center of the agrarian problem. One should keep in mind that the Kadro authors agreed on virtually all issues evaluated in the journal. Therefore, views proposed on the issue of the agrarian question represent the views of the movement, although basically two of the Kadro authors, İsmail Hüsrev Tökin and Vedat Nedim Tör, wrote extensively on this subject. After introducing the journal and the authors, we will first present the theoretical principles that Tökin used in his work (1990) and, second, discuss the Kadro Movement's perception of the agrarian question in Turkey. A discussion on Kadro's agrarian program, first on land reform and then on agricultural cooperatives, will follow. An evaluation of Kadro's approach to the agrarian question will conclude the study.

1. ERtan (1994); Türkeș (1998, 1999); ÖZveren (1996, 2002); Harris (2002); Tekeli \& İlkì (2003); ÖZGÜR (2006); YANARDAĞ (2008). 


\section{KADRO IN A NUTSHELL}

The principal contributors to the journal were Şevket Süreyya Aydemir, Burhan Asaf Belge, Vedat Nedim Tör, İsmail Hüsrev Tökin and Yakup Kadri Karaosmanoğlu, and they made clear their aim for publishing the journal in its first issue. For them, since the proclamation of the republican regime in 1923, Turkey had been undergoing a revolution which has not yet ended. All the movements witnessed thus far, have simply been a phase of this revolution. The country has lived through an insurrection; however, insurrection is not the aim but the tool of a revolution. If the movement had stopped at the phase of insurrection the revolution would have failed. On the contrary, it was growing stronger and had not yet presented its final œuvre. To build a distinct Turkish society on the foundations laid, the movement had to continue growing. The will of the revolution was represented by the will of an avant-garde group, outnumbered but conscious. This avant-garde group had to comprehend principles deducted from, and theorized by, the realities of the revolution. The deepening of the revolution, first and foremost, involved the dissemination of these principles among young generations of both urban and rural populations. As these theoretical and ideological elements were explained, they would forge the criteria for the generation of the revolution, and they would create a standard revolutionary type. This type would assess developments with these criteria in mind, he/she would think with the same norms, he/she would reach the same conclusions and, therefore, the peculiar system of understanding the world of the revolution would be created (Kadro, 1932: 3).

Thus, the aim of the Kadro authors was to provide the Turkish Revolution with an ideology that had not yet been developed. Such an assertive aim created the journal and the movement, but at the same time, since it disturbed the prominent figures of the ruling party of the time, it was one of the factors that brought about the end of the movement and the journal (Tekeli \& İlkin, 2003).

Kadro published articles on a wide range of subjects. Literature, education, economics, politics, art, sociology, social policies, agriculture, history and technology were among the subjects covered by the journal. With the exception of Yakup Kadri Karaosmanoğlu, all members of the Movement were either involved in, or influenced by, the revolutionary movements of their time. Şevket Süreyya, who can be seen as the leader of the Movement, spent several years in Azerbaijan, Dagestan and Georgia after the First World War. Even though his Eastern incursion started with Pan-Turkic ideals, he ended up being influenced deeply by the Russian Revolution and Bolshevism. He taught in Azerbaijan and later studied in post-revolutionary Moscow, becoming a member of the Communist Party. In 1923 he returned to Turkey and in 1925 he was arrested for being a member of the Turkish Communist Party and sentenced to ten years imprisonment. He was released one and a 
half years later, thanks to a general amnesty. In 1927 he was arrested again, but was set free after a four-month trial. After 1928, he worked in the service of the Republic, and he was a prominent figure in the publication of Kadro. After the closure of the journal, he continued to work for the government in various capacities until 1950.

İsmail Hüsrev Tökin also lived in post-revolutionary Russia and studied in the Communist University of the Toilers of the East in Moscow. After he returned to Turkey, he worked for a German company for a while, then for State Railways and the Agricultural Bank. His book, Türkiye Köy İktisadiyatr, in which he made a detailed analysis of social and production relations in rural Turkey, was published in 1934. After the closure of Kadro, İsmail Hüsrev continued to work as an economist in a state-owned bank (Sümerbank), the Ministry of Trade, and the Ministry of Economics.

Vedat Nedim Tör and Burhan Asaf Belge both studied in Germany, economics and civil engineering respectively, during and after the First World War. They were influenced by the rising revolutionary momentum that followed the defeat of Germany. Vedat Nedim returned to Turkey in 1922, the same year he received his $\mathrm{PhD}$ at the University of Berlin, and started to write in the Aydinlik (Illumination) journal. Burhan Asaf also graduated in 1922, and he also wrote for Aydmllk. In 1925, Vedat Nedim and Burhan Asaf were arrested, along with Şevket Süreyya, and were released in 1926. In 1927, Vedat Nedim was arrested again, but was released soon after. During and after the publication of Kadro, they worked for the government in different departments, as did other Kadro authors.

Yakup Kadri Karaosmanoğlu was from an influential family whose economic basis was based on large estates located in Manisa province in the Western Anatolia and, unlike the other members of the Kadro Movement, he was in Turkey during the War of Independence and was not influenced by revolutionary leftist movements of the time. He was elected to the Parliament during and after the war. He was a member of the literary avantgarde, was the owner of the Kadro journal and, as such, provided a vital link between Kadro and the presidential circles that initially tolerated, yet later terminated, the publication of the journal.

The communist past of the four Kadro authors was never forgotten. No matter how frequently and how sincerely they declared their admiration for, and devotion to, the new regime of the Republic, they were always viewed as ex-communists by right-wing conservative circles (Alemdar, 1978: 26-34). At the same time, they were considered untrustworthy and/or renegade by the communist groups, who felt that they had turned their backs on their ideals in order to gain political power (Kıvilcıml1, 2009: 64-7). 
The division of labor in the Kadro journal was largely determined by the social status and educational endowments of the authors. Şevket Süreyya had a unique role in the Movement. According to Tekeli and Illkin, without him, it would not have been possible to realize the existence of the Movement. Yakup Kadri was the associative figure, the chief or maestro of the Movement, and the franchise holder of the journal. Vedat Nedim's disciplined character made him the perfect choice for an editor. Şevket Süreyya was the author of the ideologically oriented articles. The literary side of the journal was represented by Yakup Kadri. Vedat Nedim wrote on the planned administration of the economy, and İsmail Hüsrev conducted theoretically oriented empirical research and focused on agricultural and monetary issues. Burhan Asaf wrote on a wide range of subjects, investigating the cultural and political trends of the period (Tekeli \& İlkin, 2003: 144-45).

\section{KADRO'S THEORETICAL FOUNDATIONS WITH REGARD TO THE AGRARIAN QUESTION}

In his Türkiye Köy İktisadiyatı, Tökin's primary concern was to explain the socio-economic structure of the rural economy of Turkey within the context of a theoretical foundation, namely, historical materialism. According to Tökin, in contrast to the economic literature available in Turkey that descriptively exposed areas of production in the agricultural sector, the science of economics was to investigate definite systems of social relations on the basis of the historical periods in which they developed. Under such close but implicit affinity to Marx's The Methods of Political Economy (1986:37-45), he asserted that the evolution of production, i.e., the adaptation of natural resources to man's needs, constituted the basis of all economic systems. Yet, production was organized differently in each society. It was realized by slaves in slave societies, by serfs in feudal societies, and by wage laborers in modern societies. All these systems belonged to particular historical eras; they appeared, they survived, and they disappeared. By referring directly to Sombart's periodization of capitalism (Sombart, 1929, 1932), in spite of his critical stand towards it in the pages where he discusses capitalist dynamics in Turkey, he put forward the view that each economic system had its sub-phases, namely, early epoch, high epoch and late epoch. Early epoch contained remnants of the previous system and developing elements of the new system; high epoch contained pure elements of the system; late epoch contained germs of the forthcoming system along with the elements of the passing system. Tökin concluded, as did Marx $(1987,1990)$ in the preface of $A$ Contribution to the Critique of Political Economy and in the chapter of Primitive Accumulation of the Capital's first volume, once again without referring to Marx, that each system was a product of the dialectical development of conflicting periods that are negations of previous ones. 
As a result of the historical characteristics of each economic system, the concepts of the science of economics were nothing but historical categories (Tökin, 1990: 9-11).

Although historical materialism constituted the core of the analysis and the specter of Marx covered the book, the name of Marx appears only once. Tökin referred to him only by name without citing the reference, as he discussed the development of capitalism and consequent exploitation of labor in Europe. The passage in question was about the exploitation of child labor and is in the chapter on General Law of Capitalist Accumulation of the first volume of Capital (Tökin, 1990: 108; Marx, 1982: 815).

In spite of an inclination towards Marxist analysis, the historical materialism of Kadro was not based on class struggle and the working classes did not constitute actors of change in the historical scene. Marxism, as the critical synthesis of German philosophy, English Political Economy and French Socialism, was based on nothing but genuine European social dynamics; the essential conflict leading to historical change (the revolution) in these industrialized metropolitan countries was class struggle between capital and labor. National liberation movements were, however, the result of distinctive historical and economic development paths that colonies (and semi-colonies) had experienced as their population had been enslaved by the order of capital-labor reigning in the industrialized countries. The essential conflict leading to historical change in colonies (and semicolonies) was, therefore, the resolution of the metropolis-colony conflict by state-led development policies (Aydemir, 1990:37-43). Under such a differentiated context, economic policies to be implemented in Turkey were to be designed by the state and representative of public interest and common good, in order to establish a free country and a society free of class conflicts (Aydemir, 1990: 48, 133, 181). The emphasis is, therefore, on the economic development and national liberation of Turkey in the capitalist world economy. Thanks to imprints of Parvus' analysis on imperialism and that of historismus on Turkey's underdevelopment in the intelligentsia of the late Ottoman era, Kadro synthesized, in the era of the Great Depression, a dependency-like approach with List-type developmentalism (Özveren, 1996; 2002: 141-42).

Indeed, discussion of the agrarian question in a non-capitalist context gave already birth to dependency-like approaches in the first decades of the twentieth century. In Romania, populist Constantin Stere's and Marxist Constantin Dobrogeanu-Gherea's discussion whether socialism was "an exotic plant" in an agricultural country, in spite of ideological conflict splitting them, departed from an argument of unequal exchange and a conceptualization of center and periphery relationship within the world economy. According to the former, vagabond capital composed of commercial and finance capital of the West plunders backward countries for a profitable investment without producing a na- 
tional wealth: it serves as a huge pump siphoning off abroad the wealth thereby accumulated (referring to Stere, 1996; Boatca, 2005: 18-9). Similarly, the latter argued that backward countries enter into the orbit of advanced capitalist countries in such a way that their social evolution is determined by the movement of advanced countries: the ascendance of commercial capital results in a kind of capitalist development despite the endurance of medieval remnants (Kitch, 1977: 74-75). Although both analyses concord fundamentally with that of Kadro, their policy prescriptions (national struggle against vagabond capital for the populist and global class struggle for the Marxist) differed largely from that of Kadro (state-led development in a classless society). From policy perspective, Kadro's approach develops however a reasoning akin to that of corporatist follower of dependencylike approach in the inter-war period Romania, Mihail Manoilescu whose analysis of unequal exchange was based on labor productivity differentials between agriculture and industry on the one hand and between capitalist and backward countries on the other (Love, 1996: 71-98).

According to Tökin, production relied on the foundation of an economic system composed of, following Sombart's analysis, three basic elements. The degree of development of an economic system depended on the degree of development of technique or forces of production, characterizing the relation of men to nature. The first element of an economic system was therefore the technique. The second was the social production relations characterizing the relations of men to men and the relations of ownership of factors of production. As technical development transformed social relations, the causality went from the first to the second element. A third element of an economic system was spirit/mentality. Spirit/mentality determined the conduct of the system. It enforced the set of values, norms and behavior of individuals. Although all these three features followed Sombart's analysis of economic systems, before concluding his theoretical introduction Tökin differentiated his analysis from that of Sombart. In Sombart's analysis, the dominant and determinant element was economic mentality. Social order and technique were products of this mentality. However, in Tökin's analysis, the starting point was the relationship between men and nature and the intermediation role played by technique (Tökin, 1990: 128; Sombart, 2001). Such a critique of Sombart's analysis followed implicitly the argument of Karl Marx found in the Preface of $A$ Contribution to the Critique of Political Economy (1859) and underlined the conditioning effect of mode of production on social, political and intellectual life. Throughout the book, presentation and discussion of each subject follows this trinity of causality which runs from technique to spirit/mentality through the interdependency of social relations. 
The most cited references from the political economy literature are those of Sombart ${ }^{2}$. Tökin cited his works on a factual basis, especially in the parts where he discussed the historical development of capitalism. They served, therefore, to Tökin as reference books on economic history. On the other hand, from a theoretical standing, Tökin's theoretical approach was loosely connected to that of Sombart by means of a critical perspective from the angle of historical materialism.

While he referred extensively to Sombart in his book, Tökin, in his discussion on agrarian dynamics, referred neither to it nor to any classical work on the agrarian question. In an interview made in 1991, İsmail Hüsrev Tökin acknowledged, however, that he had studied Kautsky's works while he was a student in Russia (Ertan, 1994: 297). In that same interview he stated that Marx's and Sombart's works were also a part of the curriculum. His avoidance of citing Kautsky (and his reluctance in citing Marx more liberally) may be seen as a sign of Kadro authors' efforts to put some distance between them and the radical left, in order to diminish the weight of potential criticism. It is also worth mentioning that Kadro's reading list exhibits a striking parallelism with that of the agrarian debates in Romania during the same period:

In the interwar era, a number of economists -some holding German doctorates-were influenced by social and economic theories then circulating in Europe, including Soviet Marxism, German and Austrian corporatism, the German "Historical" school of Schmoller, and Chayanov's theories on peasant economics. The influence ofWerner Sombart and Rudolf Hilferding was especially notable, and many non-Marxists subscribed to Hilferding's periodization of the history of capitalism into commercial, industrial, and financial phases, to which corresponded the ideologies of mercantilism, liberalism, and imperialism (Love, 1990: 81).

On the other hand, sources cited in the book consist mostly of works in which Tökin extracted statistical and factual data on the agricultural sector in Turkey. In his discussion of the agricultural structure, especially on technical issues, Tökin referred also to two famous agronomists of the early twentieth century, Friedrich Aereboe and G. Studen$\mathrm{sky}^{3}$. Tökin integrated other factual evidence, while studying the development of capitalism on a world scale, from several authors whose theoretical approach also matches

2. SOMBART (1927a) was cited in TÖKIN (1990: 14, 156); SOMBART (1927b) was cited in TöKIN (1990: 87, 96, 98, 99, 100, 102); SOMBART (1927c) was cited in TökIN (1990: 86, 95, 108); SOMBART (1904) was cited in TöKIN (1990: 110).

3. Aereboe (1928) was cited in TöKIN (1990: 60); STUdENSKy (1930) was cited in TöKIN (1990: 198); STUDENSKY (1931) was cited in TöKIN (1990: 199-200). 
that of Kadro, such as the Soviet historian Nikolai Mikhailovich Lukin, the English economist John A. Hobson and the German statistician Rolf Wagenführ ${ }^{4}$. Citation of Hobson's Imperialism reflects once again on how their dependency-like analysis was built on the destructive effects of European capitalism in the world economy, in general, and in Turkey, in particular.

\section{THE AGRARIAN QUESTION AND RURAL ECONOMY IN TURKEY}

Before discussing rural economy in Turkey, it might be useful to present a snapshot of the political context and structure in Turkey in the 1930s. Following two failed attempts to transcend the political system from a one-party regime to a multi-party democracy, a political system based on a single-party administration was firmly established in the beginning of the 1930s. The ruling party was the Republican People's Party (RPP), founded originally as the People's Party by the leader of the Independence War, Mustafa Kemal. The ideology and the system based on this creed formed during this one-party period was called Kemalism, which has been praised, criticized and discussed since then. It evolved gradually on a base of six principles declared in the RPP program of 1931. These six principles, which became a part of the Constitution of the Republic in 1937, are republicanism, secularism, nationalism, populism, etatism (statism) and revolutionism (Zürcher, 2004: 181).

Of these six principles, populism and etatism are closely related to the subject matter of this work. At the heart of populism lies the notion of national solidarity. The interests of the nation come before those of any group or class. As a matter of fact, the ruling ideology rejected the existence of social classes in the European sense in Turkish society (Zürcher, 2004: 182). Instead of classes, the society consisted of occupational groups, such as farmers, workers, merchants, artisans or landowners. The ruling party represented all members of society as well as protected the interests of all these occupational groups. According to Parla and Davison (2004: 81), Mustafa Kemal and the RPP used their view of "the people" to justify their sole position as rulers in the state -that is, to enforce and reinforce their position as the representatives of all interests in society and over and against those they considered to be representatives of the interests of particular sectors and classes.

The non-existence of classes made socialism inconceivable and the turmoil perceived in the Western capitalist world discredited liberal policies. The result was to embrace

4. LuKIN (1923) was cited in TöKIN (1990: 95); Russian translation of HobSON (1902) was cited in TÖKIN (1990: 111); WAGENFÜHR (1933) was cited in TöKIN (1990: 125). 
etatism as a way of economic development. Etatism, according to Parla and Davison (2004: 131), was the way of both promoting and enhancing the role of the state in capitalist accumulation, and at the same time disciplining a nationalist workforce. Ahmad (1993: 62) points out that the balance that could be reached through state intervention in the economy and society would never be possible in a liberal system. The disciplined society and the state of harmony in single-party regimes certainly impressed the prominent figures of the RPP.

As already stated, İsmail Hüsrev Tökin, in his preface to Türkiye Köy İktisadiyatı ("The Rural Economy of Turkey"), argued that an economist who might travel Turkey from its western to eastern frontiers would face diverse social and economic scenes: remnants from the previous centuries, in both their mature and embryonic forms. In other words, feudal manors, large sharecropping farms, capitalist farms, and small peasant farms, which he analyzed throughout his book. The analysis of Tökin follows that of Karl Kautsky. The latter had already underlined that:

Contemporary society is ruled by the capitalist mode of production. Its distinctive character-and the moving force of our age-comes from the antithesis between the capitalist class and the wage-proletariat. However, the capitalist mode of production is not the only form of production in contemporary society; it exists alongside the remains of pre-capitalist modes of production, which have maintained themselves into the present day. The germs of new, higher modes of production can also be detected in some of the forms of state or municipal activity, and in the cooperative system (Kautsky, 1988: 9).

Indeed, another important theoretician of the agrarian question, Alexander Chayanov made the same point as follows:

Even today, significant blocs of peasant family labor units are interspersed in capitalist world economy. Economic formations that resemble slave or feudal economic types are still interspersed in the colonies and the states of Asia. Analyzing the economic past, we more frequently, one may say constantly, come across the fact of such coexistence, sometimes the beginnings of capitalism together with the feudal or serf system, sometimes the slave economy next to serfdom and the free family labor economy, etc. (Chayanov, 1966: 27).

The agrarian question, in its narrowest sense, deals with the ways and methods of eradicating pre-capitalist agricultural relations of production that survive in a capitalist setting. In its broadest meaning, according to Byres: 
The agrarian question may be defined as the continuing existence in the countryside of a poor country of substantive obstacles to an unleashing of the forces capable of generating economic development, both inside and outside agriculture. Originally formulated with respect to incomplete capitalist transition, and certain political consequences of that incompleteness, the agrarian question also became part of the debate on the possibility of socialist transition in poor countries (Byres, 2012: 13).

Benjamin (1926:349) states that [...] European socialists, particularly in the Continental countries of Western Europe, have been publishing books and pamphlets upon the agricultural problem ever since the formation of the first International Workingmen's Association (the so-called "Internationale") in 1864. Hence, the agrarian question is a product of the second half of the nineteenth century, and those who were interested in it were mainly socialist and/or social democrat thinkers. Although Byres (2012:10) argues that the origins of the question go back to Engels' The Peasant Question in France and Germany (1894), its popularity amplified after the publication of Kautsky's The Agrarian Question (1899) and Lenin's Development of Capitalism in Russia (1899).

In the Manifesto of the Communist Party (1848), Marx and Engels argued that:

The lower strata of the middle class -the small tradespeople, shopkeepers, and retired tradesmen generally, the handicraftsmen and the peasants-all these sink gradually into the proletariat, partly because their diminutive capital does not suffice for the scale on which Modern Industry is carried on, and is swamped in the competition with the large capitalists, partly because their specialised skill is rendered worthless by new methods of production (Marx \& Engels, 2008: 16).

According to Marx, concentration of capital in industry (i.e., the disappearance of small-scale manufacturers and the dominance of large establishments), was an inevitable result of capitalist development, and this would also be the case for the agricultural sector. In his discussion of the production of relative surplus value, he stated that:

In the sphere of agriculture, large-scale industry has a more revolutionary effect than elsewhere, for the reason that it annihilates the bulwark of the old society, the "peasant", and substitutes for him the wage-labourer. Thus the need for social transformation, and the antagonism of the classes, reaches the same level in the countryside as it has attained in the towns (Marx, 1990: 637).

On the other hand, as Tom Brass underlined, Marx (1990: 799) also acknowledged the reproduction of categories of unfree labor during the capital accumulation, [a] $c c u-$ 
mulation of wealth at one pole is, therefore, at the same time accumulation of misery, the torment of labour, slavery, ignorance, brutalization and moral degradation at the opposite pole, i.e., on the side of the class that produces its own product as capital (Brass, 2011: 51-2).

White slaves of capitalist farmers and women and children depending on the gang system in England, on the one hand, and Negro slaves of capitalist plantations in America and corvée labor of Wallachian peasants serving the boyars, on the other, were examples of such a process in a world market dominated by the capitalist mode of production (Marx, 1990: 344-48, 830, 850-53).

The starting point of Kautsky (1988: 11) was, following the Breslau congress of German social democrats (1895), that [agriculture] follows its own laws of development, which are different from those of industry. As Marx analyzed the tendency of the profit rate to fall, in the third volume of Capital, Kautsky analyzed tendencies of, and counter-tendencies to, the extension of capitalist production, the concentration of landed property, and the proletarianization of agriculture (Hussain \& Tribe, 1981: 105-6). In contrast to Lenin, who was interested merely in the capitalist class differentiation of the peasantry (Lenin, 1977), his main concern was the role of pre-capitalist and non-capitalist forms of agriculture within capitalist society (Kautsky, 1988: 3). The participants to the debate on agrarian question in the Balkan countries, such as Constantin Stere, referred mostly to Kautsky and argued that agriculture has its own laws of development which are not subject to the Marx's laws of concentration of capital (Love, 1996: 34, 62-3).

Tökin discussed the historical development of non-capitalist and capitalist forms of agriculture in Turkey in the context of such literature on the agrarian question with which he was already familiar. First, he characterized the Ottoman economic system as a seigniorial regime (derebeylik nizami), in which a rich and powerful class employed external working forces on its own property to meet its subsistence. This class possessed the land and dominated forcefully the work force (Tökin, 1990: 153-54). According to him, in Republican Turkey, the seigniorial regime and its social relations survived, yet they changed forms and went through a metamorphosis depending on the local and historical conditions of each locality. Thus, the social fabric of Anatolia was unable to break away from these remnants of the Middle Ages (Tökin, 1990: 176). Indeed, this followed implicitly on Marx's analysis on the commodity in the first pages of the first volume of Capital, and Sombart's differentiation between sustenance and the exchange economy in der Moderne Kapitalismus, as a commodity economy system based on production for a market developed at the expense of the natural economy system based on autarkic principles, economic activities started to dissolve; production and consumption became differentiated in such a way as to establish specialization in localities and enterprises in agri- 
cultural and industrial production; and the division of labor and market relations were amplified at the national level (Tökin, 1990: 20-39, 64-74; Marx, 1990; Nussbaum, 1968: 17-60).

Although Tökin gave priority to production activities in order to characterize economic systems, he proposed, following Sombart (2001: 11) and anticipating to a certain extent Paul Sweezy (1950), Fernand Braudel (1979) and Immanuel Wallerstein's (1974) analysis of capitalist development, that movement of commodities, in other words the market, dominated and organized economic activities. According to him, it was the interdependence of the commodities that constituted social production relations. For the producer, the market was nothing but an enigmatic place that had suzerain power over, and outside, the authority of individuals (Tökin, 1990: 79-82). The development of the capitalist economic system based on a society of commodity exchange would structure and differentiate Turkey's rural economy within the world economy (Tökin, 1990: 83).

According to Tökin, capitalism, as it expanded and diffused throughout the world, evolved through different phases. He did, however, distance himself from the periodization of Sombart (1932) (Frühkapitalismus, Hochkapitalismus, Spaetkapitalismus), because of the reign of spiritual and immaterial dynamics and the insufficiency of class analysis in the characterization of each period; he followed, rather, Hilferding's periodization of capitalism: first commercial, then industrial and finally financial capital dominated the economic system (Tökin, 1990: 83-6; Hilferding, 1981). In this context, the Ottoman economy became in the nineteenth century a dependent one on the reign of financial capital. Within the world economy it specialized in agricultural and raw material production and was subjected to the conjectural movements of European industrial markets. Its main aim was to transfer the surplus it produced to capitalist markets (Tökin, 1990: 113-32). Interestingly, such an argument was nothing but an extension of the argument already advanced in the 1910s by Alexander Israel Helphand (Parvus) on the exploitive effects of European imperialism on Ottoman lands (Karaömerlioğlu, 2013: 18-9; Dumont, 1980: 79-82).

In the first decade of the twentieth century, Constantin Dobrogeanu-Gherea (1945) advanced indeed a similar analysis for Romania: backward countries were entering into the orbit of advanced countries as capitalist world economy expanded. What made his point original was however that, according to him, in the backward countries Marxist laws of development manifested themselves in a much more complex way than in capitalist ones. Romania at the turn of the twentieth century had a legal structure of a capitalist society without having capitalist class and proletariat: 
Backward countries in the capitalist orbit suffered both from capitalism (in Romania, boyar exploitation of peasants to maximize profits in the international market) and the insufficient development of capitalism (its incapacity locally to destroy feudal relations of production) (Dobrogeanu-Gherea in Love, 1990: 79).

It was the landholding class (boyars) who created the liberal state in Romania, but the local bourgeoisie who took their place as a new "semifeudal class" kept intact pre-capitalist social and economic relations in the countryside: the peasant was fixed to the lord's lands; he was forced to provide corvée labor for his master; he had to pay tribute in kind as well as other forms of feudal dues. Dobrogeanu-Gherea named this hybrid form of Romanian peasantry as neo-serfdom (neoiobagia), since relations of production were largely feudal; liberal legal system left the peasant at the mercy of the landlord; relations between landlords and workers were regulated by a legislation that brought about the inalienability of peasant land; by lacking land for his subsistence, small peasant farmer was forced to become a vassal laborer or sharecropper of the landlord (Love, 1990: 79-80; Kitch, 1977: 79-81; Stahl, 1978: 111-12).

Discussion on the effects of expansion of capitalist world economy on labor regime converges to a certain extent in the analysis of Dobrogeanu-Gherea and that ofTökin. As the former introduced the concept of neo-serfdom to describe amalgamation of capitalist and feudal regimes in Romanian countryside, Tökin differentiated four labor regimes to describe coexistence of different modes of production operating in Turkey's countryside: wage laborers, small producers, sharecroppers, serfs. In the first place, as the commodity economy developed, according to Tökin (1990: 134), labor power also became a commodity to be sold in the labor market. The growing indebtedness of the peasantry (in the form of credits-in-kind, or money, or the truck system) resulted in the general expropriation of their properties and the establishment of new socio-economic relations in the countryside (Tökin, 1990: 146-51). As peasants lost their power over the forces of production and became laborers, entrepreneur producers intensified their hold over them and became capitalists. In Western Anatolia and the Adana region, such socio-economic relations developed as the commodity economy system flourished, dependent on the international division of labor in large landed properties. The capitalist economic system in these coastal regions also brought about a profit-maximizing motive in organizing the production process. Tökin (1990: 134-35, 194) categorized this type of property as capitalist enterprise.

On the other hand, in Western, Northern and Central Anatolia, small family production units cultivating small properties (dwarf enterprises) survived along with these profit-oriented capitalist enterprises. They engaged in agricultural production within the 
context of the commodity economy system, but they did not need any labor besides family labor. According to Tökin (1990: 139-40, 194-95), on the basis of social dispersion and differentiation among them, the majority of producers working on these small units were inclined either to ascend to the level of entrepreneur producer units or descend to the level of wage laboring class.

In addition to these socio-economic units, in Western and Central Anatolia, there also existed large units in which sharecropping relations of varying degrees prevailed. As Ottoman feudalism lived through metamorphosis, the legal ties of peasantry to the landlord disappeared but their economic ties survived. According to Tökin (1990: 186-94), sharecropper families living in large properties under the control of landlords (toprak ağalı̆g oscillated between the categories of wage laborer and tenant farmer, depending on conditions in the commodity economy system.

The fourth type of socio-economic units consisted of seigniorial estates (derebeylik). They prevailed essentially in Eastern and Southeastern Anatolia. Chieftains (aşiret reisleri ve ağalar) owned, by means of force and oppression, all factors of production used by peasants; instead of economic ties, legal ties defined the relationship between chieftains and peasants. These estates were outside the commodity economy system and lived within the natural economy system (Tökin, 1990: 176-81, 193-94).

Hence, Tökin categorized four types of property units and respective labor use in the Republic of Turkey, anticipating to a certain extent Wallerstein's three types of labor use (free labor, sharecropper, slavery/coerced cash-crop labor) which depended on the degree of regional integration within the world economy (Wallerstein, 1974: 103): capitalist exploitation using wage laborers, small peasant properties with family labor, large properties cultivated with sharecropping labor, and feudal estates with peasants tied to chieftains. He proposed that the abundance and cheapness of labor power on the one hand, and the poverty of the peasants, on the other, constituted the main obstacles to technological development. The small peasantry, because of their poor economic conditions (for the most part indebtedness), could not introduce technological improvements; capitalist enterprises and sharecropping units refused to adopt new technology because of its higher cost as compared to the cheapness of labor; and feudal estates as socio-political units subsisted within the natural economy system, the foundation of which was opposed to any technological development (Tökin, 1990: 193-203).

Such a categorization of property units and discussion of their dynamics calls for, once again, Kautsky's analysis of capitalist agriculture. He argued that: 
[t] he commodity which the small farmer produces "in abundance" is precisely that means of production urgently required by the large farm -labour-power. Once things have reached this state, large and small-scale farming are not mutually exclusive. In fact, like capitalist and proletarian, they require each other, with the small farm increasingly assuming the latter role (Kautsky, 1988: 166-67).

The argument that small peasantry, sharecroppers and peasants tied to chieftains fed the reserve army of labor for capitalist agriculture in Turkey confirms that of Kautsky; but the fact that their low costs constituted an obstruction to technological development in capitalist agriculture enriches it by introducing a new dimension in the era of the Great Depression.

\section{KADRO'S AGRARIAN PROGRAM: "POPULIST" LAND REFORM}

The socialist and social democrat discussions from the last quarter of the nineteenth century concerning the agrarian program to be followed focused, on the one hand, on the nationalization of land, and on the other, on the agricultural cooperatives (Hussain \& Tribe, 1981: 8-19). Kadro addressed these questions in their agrarian policy prescriptions by following their theoretical discussions meticulously. In the agricultural sector in Turkey, as Kadro clearly demonstrated, capitalist and pre-capitalist modes of production co-existed during the 1930s. This co-existence posed serious challenges to agricultural development; however, the solution was not to eliminate all pre-capitalist structures, or to socialize the whole agricultural structure. A pre-capitalist mode of production, feudal relations in agriculture, must definitely be abolished, according to the Kadro authors. These relations created not only economic problems, but more importantly, social and political problems. The feudal relations that dominated the agricultural structure in the eastern provinces of Turkey were sources of backwardness, underdevelopment, insurrection and religious extremism. Lands that belonged to feudal lords had to be confiscated and distributed to landless peasants free of charge. Buying the land from the feudal lord and selling it to peasants could not, however, result in positive outcomes; as long as the land could change hands through sale or debt relations, it would only change the type of dependency between lord and peasant, and bring about a replacement of previous feudal relations with debt relations, a point that Dobrogeanu-Gherea underlined also with his conception of neo-serfdom that emerged after the failure of successive Romanian agrarian reforms of nineteenth and twentieth centuries (Love, 1976; Kitch, 1977; Stahl, 1978). Kadro authors insisted that land had to be confiscated and redistributed but, at the same time, the state had to provide credit and a means of production to the peasantry to prevent a change of hands of the land. In order to radically alter the existing agricultural structure in those 
areas, feudal lords also had to be exiled, and the ones who resisted had to be eliminated (Tökin, 1933c: 36-7; Tör, 1932: 25).

This proposal coincides with Joaquín Maurín's solution for the agrarian question in Spain. Maurín, an influential figure in Spanish communist movement in the 1930s, maintained that the feudal oligarchy had obstructed the development of the productive forces because they realized this would reduce their own political, economic and social power (Sennett, 2014: 139). Maurín argued that land redistribution would not be sufficient to solve the agrarian question. Similar to Kadro authors, he stated that the peasants had to have access to the means of turning the land into a productive resource. Nevertheless, a difference between these two approaches is that Maurin's analysis was based on class relations as that of Kadro on economic growth. He claimed that the agrarian revolution could be realized through state-planned land nationalization and collective farming, and such a revolution was a prerequisite for industrial development. An agrarian revolution was inseparable from industrial modernization and the working class would be the leading agent of this transformation, in alliance with the peasantry (Sennett, 2014: 149). Similarly, being disappointed with the Republican government's agrarian policies, Andreu Nin (1931: 5), another leading figure in Spanish political life, stated that their slogan then, must be the complete realization of the democratic revolution, solving the agrarian problem by expropriation without compensation of large landed estates and the distribution of land to the peasants. As we will see next, Kadro authors were in favor of a populist land reform instead of a revolutionary one, furthermore they offered different solutions for different regions, depending on the land tenure system.

Another pre-capitalist structure, sharecropping, which was an inefficient method of production, also had to be eliminated, according to Kadro. However, their attitude towards the elimination of sharecropping was not as radical as their attitude towards feudal relations. Tökin mentioned two types of sharecropping in Turkey. In the first type, big landowners rented their lands to landless peasants; in the second type, small landowners who lost their lands to usurers (creditors) worked on their previously owned properties on behalf of the creditors. In order to eliminate the first type, the government could buy large estates and distribute them to peasants. To eliminate the second type of sharecropping the government could pay off the debts of the peasants (Tökin, 1933c: 37).

Therefore, according to Kadro, land reform was necessary. The abolition of existing property relations on land could take two forms: socialist and populist land reforms. In revolutionary socialist land reform, private property on land had to be abolished, and a collectivist system had to be established. In the case of populist land reform, on the other hand, the aim of the state was to give property rights on land to people. Within the at- 
mosphere of the agrarian populism of the interwar period (Karaömerlioğlu, 2000: 12729 ; 2001), Kadro authors argued that a populist land reform, based on small propertyholding peasantry, would prevent the social polarization that threatened national unity and increase their loyalty to the national revolutionary movement. In addition, by making peasants the owners of their lands, it would rationalize agricultural production and increase the national income (Tökin, 1933b: 24; 1933c: 33). It is striking that in Balkan countries during the inter-war period, politicians, agronomists and economists viewed land reform in contrast to Kadro as a tool to solve the social question of peasantry (Daskalov, 2014: 284).

According to Tör, individual peasants could not, however, take care of their properties and their produce and, furthermore, could not even pursue their own self-interests. Property rights on land were natural rights but they had to be exercised in line with national interests. Because agriculture was a nation's work, Tör stated that the progress of agriculture had to be governed, not by individual interests, but by the state representing the highest authority of national interests. Although socialization of land was never on Kadro's agenda, Tör (1933c: 13-4; 1933a: 16) argued that property rights on land had to be guided by an etatist agricultural policy in such a way as to become compatible with national interests. This is another point that distinguished Kadro from the populist agrarian philosophy reigning in Balkan countries with a corporatist agenda based on estatist organizations (Daskalov, 2014: 299-305, 326-27).

The Kadro authors stubbornly maintained that without an etatist economic policy, it would be impossible to achieve economic development in Turkey. This was the case for industrial and agricultural development. Land and labor had to be organized through an etatist policy and agricultural relations had to be conducted within a planned economy (Tör, 1933c: 15). The plans prepared for this purpose had to be detailed and had to take into account the different characteristics of the different regions and their differing produce. Partial interventions, such as distributing animals for breeding or superior seeds, or offering credits and education, would not be sufficient to create an advanced agricultural structure (Tör, 1933b: 18).

The Kadro authors found, however, that profit-motivated large capitalist farms were compatible with the interests of rural Turkey. They stated that these farms had developed mostly in parts of the country where the commodity economy was advanced. In the majority of these enterprises modern machinery and rational systems were employed (Tökin, 1933b: 22). Although they forcefully argued that feudal relations and sharecropping had to be abolished, and those lands had to be distributed to the landless peasantry, they believed, differing from the wide range of protagonists of land reform, that there was no rea- 
son to divide large capitalist farms that used modern technology and engaged in efficiency gains. Hence, land reform was not reasonable for these enterprises (Tökin, 1933c: 36). There was therefore no contradiction between appreciating the efficiency of large-scale farming and supporting small-land ownership (Tör, 1933c: 15). Such an argument and policy preference revealed two correlated imperatives of the Kadro writers: technological development in the agricultural sector and increase of agricultural output.

Accordingly, on the issue of large capitalist farms Kadro's proposals correspond to the Spanish Republican Government's policies which guaranteed the security of private property on land and that it could be expropriated only for reasons of public utility and with a corresponding indemnity (Nin, 1931:2). In like manner, a well-known agronomist of the time, and an active promoter of land reform, Pascual Carrión supported the seizure of undeveloped land, while defending the legitimacy of the property of those who kept their lands cultivated (Lieberman, 1982: 58).

To sum up, from an economic perspective, the Kadro writers searched for reform policies in order to create an agricultural sector that would be based on (large and small) private property whose cultivation would be under the guidance of an etatist policy; and from a political perspective, they searched for reform policies to curb the power of alternative power holders and then create a uniform political center that would pursue economic policies centered on national development and liberation. In fact, the combination of both perspectives would lead to an economic and political environment favoring, to a certain extent, the already existing large property holders engaging in capitalist farming. Indeed, as Tör underlined (1933c: 16-7), one of the core principles of an etatist agricultural policy was profit-oriented cultivation. Such a preference, in contrast to Kautsky's and most of the social democrat agrarian program based on the rejection of capitalist agriculture (Kautsky, 1988), was well suited to the objectives of the Kadro writers, who searched for the development of a national, although capitalist, economy guided by the state in order to resolve the metropolis-colony conflict. The land reform that they proposed revealed, therefore, simultaneously populist (land reform to give land to the peasants), liberal (land reform for national bourgeois liberation) and conservative (land reform for the social status quo) characteristics, rather than a radical model searching for social change (Janvry, 1981:390-91).

\section{KADRO'S AGRARIAN PROGRAM: AGRICULTURAL COOPERATIVES}

In 1932, when agricultural cooperatives were once more the order of the day (Karaömerlioğlu, 2000: 82) in the context of the Great Depression, Tökin published a 
small book exposing the basic characteristics of the agricultural cooperative movement in Europe and Turkey (Tökin, 1932). The intellectuals had already discussed them during the last decade of the Ottoman Empire, within the context of the "national economy" approach, from the perspective of local notables who were suffering from fierce competition from foreign capitalists in the export market (Toprak, 1995: 125-44; YildirirKocabaş, 2010: 67-102). The discussion of the early 1930s well reflected, under currents of economic development, the perspectives of agrarian ideologies favoring the small peasantry (Yıldırır-Kocabaş, 2010: 114-36). Within such a context, Kadro's approach showed some parallelism with the discussion of the agrarian question in the Russia of 1917, when the League for Agrarian Reforms was organized by social agronomists, including Chayanov (Stanziani, 1998: 184-92). The aim of the League, according to Danilov (1991: xxv), was to generate a discussion of the agrarian question along with its solutions:

[...] co-operative peasant farm should form the foundation of the agrarian system; this transfer should take place on the basis of a state plan for land organization [...] without damaging the productive effort of [...] national economy; land organization is only a part of the solution to the agrarian problem, which involves all matters connected with the general conditions of agricultural production, the organization of self-employed peasant farms and the organization of links between these farms and the world economy as a whole (Danilov, 1991: xxv-xxvI).

The similarities between Kadro's views and the three points above are noteworthy. In order to create an efficient agricultural system the Kadro authors proposed the formation of agricultural cooperatives, production associations and production corporations. These formations would eliminate the drawbacks of small land ownership and, thanks to the opportunities created by these formations, small landowners would be able to benefit from the advantages of large-scale enterprises (Tökin, 1933c: 38). According to Kadro, all phases of agricultural production had to be controlled by mandatory state cooperatives. Through these cooperatives private property on land would be consolidated and the shares of peasants in these cooperatives would be determined by the size of their properties (Tör, 1934: 13; Tökin, 1933c: 38). The state cooperative that they had in mind was a partnership between the state and the producer. In a state cooperative, the producer would not lose his/her income or property. In this organization, the state would organize and conduct production on a national scale. In conjunction with this function of the state, the peasant would participate in production with his labor and land. The income created through this partnership -organization and management provided by the state and land and labor provided by the producer- would be divided between the state and the peasantry (Tör, 1932: 16). 
According to Tör, a mandatory state cooperative was totally different from the cooperative organization with which they were familiar. A cooperative in its traditional meaning was an organization which protected the narrow interests of small producers by granting them a small part of the profit. This type of organization would not allow capital accumulation on a national scale; on the contrary, it was a backward organization which divided the realized profit for personal interests (Tör, 1932: 16). However, the cooperative that they suggested would increase agricultural income, bring about capital accumulation in agriculture, and create a domestic market for the national industry. Considering world conditions in the 1930s, the only way of developing a national industry was to create a domestic market for its products. Given the large population employed in agriculture, creating a large domestic market in rural Turkey through increasing agricultural incomes would be the wisest way to develop both the agricultural and the industrial sectors. We should bear in mind, once again, that these cooperatives had to be organized through an agricultural plan and therefore they must be a part of the etatist policies of the administration.

The agrarian movement led by Alexander Stamboliski in Bulgaria of the interwar period favored cooperative organizations in order to cope with peasant's desperate economic situation and alleviate destructive effects of capitalist system (Bell, 1977: 66, 71-2). Croatian Peasant Party animated the cooperative movement by the idea of economic emancipation of the peasantry (Daskalov, 2014: 338). Serbian Peasant Party declared, neither a capitalist state nor a communist state, but only the cooperative state, creates an order in which everyone keeps the fruits of his labor and there are no oppressors and no oppressed (Daskalov, 2014: 342). The populist and corporatist Romanian authors proposed however the establishment of agricultural cooperatives not as an alternative to a capitalist economy, but as a capitalist alternative to industrialized development (Boatca, 2005: 22). Alongside with the Romanian populists, especially with Constantin Stere, Kadro's policy proposal on cooperatives diverges from that of other Balkan peasant parties by their objective of economic growth.

Kadro authors argue that all the phases of production must be organized and controlled by the state. This is consistent with Chayanov's idea of vertical concentration. He states that:

the most important means of achieving concentration of peasant households has to be one of vertical concentration. It must take co-operative forms, since only in these forms will it be organically linked with agricultural production and capable of acquiring the necessary depth. In other words, the only path which is possible under our conditions for introducing into the peasant economy elements of a large-scale 
economy, of industrialization and of state planning, is the path of co-operative collectivization, the gradual and consecutive separation of particular sectors of specialization from individual households and their organization as public enterprise (Chayanov, 1991: 21).

A planned agricultural system could maximize the utility received from the existence of property rights by increasing the volume of production. Lack of knowledge and organization made the concept of property rights a fictitious and useless notion. However, if individuals became a part of work plans prepared for the main branches of agriculture, they could attain freedom and wealth (Tör, 1933c: 15). Profitable production was one of the main goals of an etatist agricultural policy. The Kadro authors called attention to the unprofitability of agricultural production in Turkey. The Great Depression, which caused a decline in agricultural income as a result of the negative terms of trade developments, was one reason, yet the main problem was structural (Tökin, 1933a: 19-22; Tör, 1933c: 17).

According to Chayanov (1991:22), with the nationalization of land and the political domination of the working masses, the agricultural system would be composed of co-operative alliances of peasants and small farmers, and introduced into the system of the planned state economy could be seen as identical to the socialist organization of agriculture. Whilst there are significant similarities between Chayanov's and Kadro's views on the agrarian question, two basic differences surface in Chayanov's above opinion. We have already stated that Kadro was against the nationalization of land, and that they supported private property on land whether large or small. The second difference is about the role of class and class struggle in an economic system. The political domination of the working masses was something that the Kadro authors would not consider at all. They argued that class relations had not developed in Turkey as much as they had developed in Western countries. Etatism (or planned development) was a way of creating an industrial country free from class struggles (Aydemir, 1932). Turkey was not a classless society, however, and in the agricultural sector class differences were more visible compared to in the industrial sector. In their minds, land reform and agricultural organization would prevent a deepening of class differences and, hence, class conflict (Tökin, 1934: 22, 26; Tör, 1934: 14), despite the fact that they foresaw large capitalist farms working together with cooperatives composed of small farming units.

\section{CONCLUSION}

The Kadro authors' perception of the agrarian question was one of national liberation similar to the resolution of metropolis-colony conflict. According to the Kadro authors, fol- 
lowing Sombart, Hobson and Hilferding's analyses on capitalist dynamics, capitalist development had historically had three successive effects in Turkey: destructive, constitutive and binding. Finally, it resulted in the development of a dependent population whose main aim was to transfer its production surplus to the capitalist centers (Tökin, 1990: 113-32). Economic policies should be based on the rejection of free-tradist laissezfaire economics in a world of unequal exchange between capitalist and non-capitalist countries. The development of an agricultural structure by means of populist land reform and mandatory state cooperatives was also necessary in order to stop the transfer of surplus to capitalist centers and to secure national independence. The agricultural structure that they imagined consisted of small landowners organized under state cooperatives and large profit-oriented enterprises. They did not intend to create a capitalist or socialist agricultural system per se, yet the system that would emerge would be compatible with the capitalist world economy as their aim was to create a profit-oriented agricultural sector geared towards increasing productivity. Kadro developed, therefore, as their Romanian counterparts did to a certain extent, an approach based on import substitution industrialization built on a developed agricultural system. However, Kadro did this in the context of a national liberation movement and, especially, in response to the Great Depression.

Terence J. Byres (2001) and Henry Bernstein (1996) categorized and discussed three problems on which the agrarian question of the nineteenth and twentieth centuries was based (Akram-Lodhi \& Kay, 2010: 198-99):

the problematics of politics, production, and accumulation [...] They centre respectively on issues of alliances between classes of urban and rural labour (both agricultural wage labour and the poor peasantry) in struggles for democracy and socialism; the development of the productive forces in farming; the contributions of agriculture to primary accumulation for industrialization (Bernstein, 1996: 25).

As for the Kadro authors' approach towards the agrarian question, we can conclude that their primary focus was on the problematics of accumulation. They addressed the production problem in so far as it was related to the accumulation problem, in order to resolve the question of productivity and technological development to boost, on the one hand, industrialization, and on the other, the creation of a domestic market for developing industries. Capitalist farms using wage-laborers should continue to enjoy higher productivity levels; land reform aimed at transforming peasants tied to feudal lords and sharecroppers into small propertied peasants; and mandatory state cooperatives composed of the small peasantry were to be created in order to adopt technological progress, thus benefiting from the advantages of larger-scale investments. In other words, the application of land reform and the creation of state cooperatives would serve to accumulate a surplus 
for import substitution industrialization policies, rather than to address the problem of production. Because the conflict of metropolis-colony would outweigh the conflict of capital and labor in Turkey, the politics problem had a limited place in the mind of the Kadro authors. It concerned them in so far as the political and economic power of feudal lords in the Eastern provinces threatened the population's loyalty to the national revolutionary movement. In such a context, there was no space for the peasants to engage in political or class struggle.

According to Byres and Bernstein, the political problem was the terrain of Engels; the production problem was the terrain of Marx, Lenin and Kautsky; and the accumulation problem was the terrain of Preobrazhensky (Byres, 2001; Bernstein, 1996). In the Kadro authors' discussion on the political issue, Engels is completely absent as they gave priority to the metropolis-colony conflict over the class conflict in the context of a national liberation movement.

In the Kadro authors' discussion on the production problem, just as Kautsky found his place within the analysis of agrarian labor dynamics in Turkey's countryside, Lenin's analysis on the development of capitalist agriculture, and the social differentiation it brought up, is totally absent. Because their discussion concerning the small peasantry and state cooperatives shows some affinity with Chayanov's analysis of Russian agriculture, the absence of Lenin's analysis of the capital-labor relationship makes sense (Bernstein, 2009). Additionally, their proposition for the establishment of state cooperatives makes them reproduce the position of Ferdinand Lasalle vis-à-vis the agrarian and social question in Germany and simultaneously distances themselves from Marx, who severely criticized, in the Critique of the Goth a Program (1875), such a policy that outweighs the social dynamics of class conflicts and annihilates the agency of working classes as a revolutionary power.

In the Kadro authors' discussion on the accumulation problem, there is no mention of Preobrazhensky who proposed, in the Soviet Union of the 1920s, a plan for socialist primitive accumulation based on the transfer of a surplus from the agricultural sector to the industrial sector (Akram-Lodhi \& Kay, 2010: 194). Nevertheless, the specter of this idea was evident in the essence of the economic policies that the Kadro authors proposed for industrialization within the context of the Great Depression of the 1930s, when Soviet-planned economy had a prestigious standing in the world economy. What made their ideas different from the others was their emphasis on the primacy of the metropolis-colony conflict, leading them to a strategy of substituting industrialization. 


\section{ACKNOWLEDGEMENTS}

An early version of this paper was presented at the $18^{\text {th }}$ European Society for the History of Economic Thought (ESHET) Annual Conference, 29-31 May 2014, Lausanne, Switzerland, with the title Kadro on Agrarian Question in Turkey. We would like to thank two anonymous referees for their constructive contributions, and also the editors of $\mathrm{His}$ toria Agraria.

\section{REFERENCES}

Aereboe, F. (1928). Agrarpolitik. Berlin: Parey.

Ahmad, F. (1993). The Making of Modern Turkey. New York: Routledge.

AKram-LodHi, A. H. \& KaY, C. (2010). Surveying the Agrarian Question (Part 1): Unearthing Foundations, Exploring Diversity. Fournal of Peasant Studies, 37 (1), 177202.

AlemDar, K. (1978). Basında Kadro Dergisi ve Kadro Hareketi İle İlgili Bazı Görüşler. In C. Alpar (Ed.), Kadro 1932-Cilt 1 (pp. 21-42). Ankara: Ankara İktisadi ve Ticari İlimler Akademisi.

Aydemir, Ş. S. (1932). Plan Mefhumu Hakkında. Kadro, 1 (5), 5-12.

Aydemir, S.. S. (1990 [1932]). Inkılap ve Kadro. 4th. ed. İstanbul: Remzi Kitabevi.

BeLl, J. D. (1977). Peasants in Power: Alexander Stamboliski and the Bulgarian Agrarian National Union, 1899-1923. Princeton: Princeton University Press.

Benjamin, G. G. (1926). German and French Socialists and the Agrarian Question. Fournal of Political Economy, 34 (3), 349-76.

Bernstein, H. (1996). Agrarian Questions Then and Now. In H. Bernstein \& T. Brass (Eds.), Agrarian Questions: Essays in Appreciation of T. F. Byres (pp. 22-59). London: Frank Cass.

BERnsteIn, H. (2009).V. I. Lenin and A.V. Chayanov: Looking Back, Looking Forward. The Fournal of Peasant Studies, 36 (1), 55-81.

Boatca, M. (2005). Peripheral Solutions to Peripheral Development:The Case of Early 20th Century Romania. Fournal of World-Systems Research, 11 (1), 3-26.

BRASs, T. (2011). Labor Regime Change in the Twenty-First Century: Unfreedom, Capitalism and Primitive Accumulation. Leiden: Brill.

BRAUDEL, F. (1979). Civilisation matérielle, économie et capitalisme, XVe-XVIIr siècle. 3 vols. Paris: Armand Colin.

Byres, T. J. (2001 [1983]). The Agrarian Question. In T. BotTomore (Ed.), A Dictionary of Marxist Thought (pp. 9-11). $2^{\text {nd }}$ ed. Oxford: Blackwell. 
Byres, T. J. (2012). The Agrarian Question and the Peasantry. In B. Fine \& A. SAADFilHo (Eds.), The Elgar Companion to Marxist Economics (pp. 10-5). Cheltenham: Edward Elgar.

Chayanov, A.V. (1966 [1924]). On the Theory of Non-Capitalist Economic Systems. In D. Thorner, B. H. Kerblay \& R. E. F. SMith (Eds.), A. V. Chayanov on the Theory of Peasant Economy (pp. 1-28). Homewood: Richard D. Irwin.

Chayanov, A. V. (1991 [1919]). The Theory of Peasant Co-operatives. Columbus: Ohio State University Press.

DANILOV, V. (1991). Introduction: Alexander Chayanov as a Theoretician of the Co-operative Movement. In A. V. Chayanov, The Theory of Peasant Co-operatives (pp. XIXxxv). Columbus: Ohio State University Press.

Daskalov, R. (2014). Agrarian Ideologies and Peasant Movements in the Balkans. In R. Daskalov \& D. Mishkova (Eds.), Entangled Histories of the Balkans. 2: Transfers of Political Ideologies and Institutions (pp. 281-354). Leiden: Brill.

Dobrogeanu-GhereA, C. (1945 [1912]). Socialismul in tarile inapoiate. Bucureşti: Partidului Social-Democrat.

Dumont, P. (1980). Un économiste social-démocrate au service de la Jeune Turquie. In R. Mantran (Ed.), Mémorial Ömer Lütfi Barkan (pp. 75-86). Paris: Librarie d'Amérique et d'Orient Adrien Maisonneuve.

ERTAN, T. F. (1994). Kadrocular ve Kadro Hareketi. Ankara: T. C. Kültür Bakanlı̆̆ Yayınları.

Harris, G. S. (2002). The Communists and the Kadro Movement: Shaping Ideology in Atatürk's Turkey. İstanbul: Isis Press.

Hilferding, R. (1981 [1910]). Finance Capital: A Study of the Latest Phase of Capitalist Development. (Ed. T. Bottomore). London: Routledge/Kegan Paul.

Hobson, J. A. (1902). Imperialism: A Study. New York: James Pott.

Hussain, A. \& Tribe, K. (1981). Marxism and the Agrarian Question. Atlantic Highlands: Humanities Press.

Janvry, A. DE (1981). The Role of Land Reform in Economic Development: Policies and Politics. American fournal of Agricultural Economics, 63 (2), 384-92.

Kadro (1932). Kadro. Kadro, 1 (1), 3.

KARAÖMERLIOĞLU, M. A. (2000). Elite Perceptions of Land Reform in Early Republican Turkey. Fournal of Peasant Studies, 27 (3), 115-41.

KARAÖMERLIOĞLU, M. A. (2001). Agrarian Populism as an Ideological Discourse of Interwar Europe. New Perspectives on Turkey, (26), 59-93.

KARAÖMERlioĞLU, M. A. (2013). Rusya, Almanya ve Türkiye'de Büyük Bir Kozmopolit Entelektüel ve Eylemci: Helphand-Parvus. In Parvus Efendi, Cihan Harbine Doğru Türkiye (pp. 7-28). İstanbul: Ayrınt1.

KaUtsky, K. (1988 [1899]). The Agrarian Question. London/Winchester: Zwan. 
Kivilciml, H. (2009 [1930-2]). Müttefik: Köylü (Bütün Eserleri 27, Yol Dizisi 5c). İstanbul: Sosyal İnsan.

KITCH, M. (1977). Constantin Dobrogeanu-Gherea and Rumanian Marxism. The Slavonic and East European Review, 55 (1), 61-89.

LeNIN, V. I. (1977 [1899]). V.I. Lenin Collected Works.Vol. 3:The Development of Capitalism in Russia. Moscow: Progress Publishers.

Lieberman, S. (1982). Contemporary Spanish Economy: A Historical Perspective. London/Boston: Allen \& Unwin.

Love, J. L. (1990). Theorizing Underdevelopment: Latin America and Romania, 18601950. Estudos Avançados, 4 (8), 62-95.

Love, J. L. (1996). Crafting the Third World: Theorizing Underdevelopment in Rumania and Brazil. Stanford: Stanford University Press.

LukIN, N. M. (1923). Noveishaia istoriia Zapadnoi Evropy. Moskva: Krasnaiia Nov.

Marx, K. \& Engels, F. (2008 [1848]). Manifesto of the Communist Party. Utrecht: Open Source Socialist Publishing.

MARX, K. (1986 [1857-58]). Economic Manuscripts of 1857-58 (First Version of Capital). In Karl Marx and Frederick Engels Collected Works.Vol. 28: Karl Marx, Economic Works: 1857-61. New York: Lawrence \& Wishart.

MARX, K. (1987 [1859]). A Contribution to the Critique of Political Economy. In Karl Marx and Frederick Engels Collected Works. Vol. 29: Karl Marx: 1857-61. New York: Lawrence \& Wishart.

MARX, K. (1990 [1867]). Capital. Vol. I. London: Penguin.

Nin, A. (1931). Revolutionary Progress in Spain:The Tasks of Spanish Communists. The Militant, 4 (10), 1-5.

Nussbaum, F. L. (1968 [1935]). A History of the Economic Institutions of Modern Europe: An Introduction to der Moderne Kapitalismus of Werner Sombart. New York: Augustus M. Kelley.

ÖzGÜr, M. E. (2006). Kadro and Its Analysis of the Great Depression. Zonguldak Karaelmas Üniversitesi Sosyal Bilimler Dergisi, 2 (4), 91-103.

Özveren, E. (1996). The Intellectual Legacy of the Kadro Movement in Retrospect. METU Studies in Development, 23 (4), 565-76.

Özveren, E. (2002). Ottoman Economic Thought and Economic Policy in Transition: Rethinking the Nineteenth Century. In M. Psalidopoulos \& M. E. Mata (Eds.), Economic Thought and Policy in Less Developed Europe:The Nineteenth Century (pp. 12944). London: Routledge.

Parla, T. \& Davison, A. (2004). Corporatist Ideology in Kemalist Turkey: Progress or Order? Syracuse: Syracuse University Press.

Sennett, A. (2014). Revolutionary Marxism in Spain, 1930-1937. Leiden: Brill.

SOMBART, W. (1904). Gewerberwesen. Leipzig: Göschen. 
Sombart, W. (1927a). Die Ordnung des Wirtschaftslebens. $2^{\text {nd }}$ rev. ed. Berlin: Julius Springer.

SOMBART, W. (1927b). Der moderne Kapitalismus: Historisch-systematische Darstellung des gesamteuropäischen Wirtschaftslebens von seinen Anfängen bis zur Gegenwart. Vols. III. München/Leipzig: Duncker \& Humblot.

SOMBART, W. (1927c). Der moderne Kapitalismus: Das Wirtschaftsleben im Zeitalter des Hochkapitalismus. Vol. I. München/Leipzig: Duncker \& Humblot.

SOMBART, W. (1929). Economic Theory and Economic History. The Economic History Review, 2 (1), 1-19.

SOMBART, W. (1932 [1927]). L'apogée du capitalisme (Der moderne Kapitalismus, trans. by S. Jankélévitch). Paris: Payot.

SOMBART, W. (2001 [1913]). The Influence of Technical Inventions. In N. STEHR \& R. GRundmann (Eds.), Economic Life in the Modern Age (pp. 229-46). London:Transaction.

SOMBART, W. (2001 [1930]). Capitalism. In N. STEHR \& R. GRUNDMANN (Eds.), Economic Life in the Modern Age (pp. 3-29). London: Transaction.

STAHL, H. (1978). Théories de C. D. Gherea sur les lois de la pénétration du capitalisme dans les "pays retardataires". Review (Fernand Braudel Center), 2 (1), 101-14.

StanZIANi, A. (1998). L'économie en révolution: Le cas russe, 1870-1930. Paris: Albin Michel.

STERE, C. (1996). Social-democratism sau poporanism? Galati: Porto-Franco.

Studensky, G. (1930). Technical Revolution in American Agriculture (in Russian). Agrarnie problemi (Fournal of the International Agricultural Institute of Moskow), (1).

STUdENSKY, G. (1931). Agrarkrisen. Weltwirtschaftiches Archiv.

SweEzy, P. M. (1950). The Transition from Feudalism to Capitalism. Science and Society, 14 (2), 134-57.

Tekeli, İ. \& İlkin, S. (2003). Bir Cumhuriyet Öykusu: Kadrocular ve Kadro'yu Anlamak. İstanbul: Turkiye Ekonomik ve Toplumsal Tarih Vakfi.

TöKIN, İ. H. (1932). Türkiyede Zirai Kooperatif Hareketi. İstanbul: Ahmet İhsan Matbaası.

TöKIN, İ. H. (1933a). Anadolu Köyünde Bünye Tahavvülü. Kadro, 2 (14), 18-24.

TökIN, İ. H. (1933b). Türk Köylüsü Bir Toprak Reformu Bekliyor. Kadro, 2 (21), 21-4.

TöKIN, İ. H. (1933c). Türk Köylüsünü Topraklandırmalı Fakat Nasıl? Kadro, 2 (23), 33-9.

TöKIn, İ. H. (1934). Millet İçinde Sinif Meselesi II. Kadro, 3 (26), 20-6.

TöKIN, İ. H. (1990 [1934]). Türkiye Köy İktisadiyatı. İstanbul: İletişim.

Toprak, Z. (1995). Milli İktisat, Milli Burjuvazi. İstanbul: Tarih Vakfi Yurt.

Tör, V. N. (1932). Findikta Devlet Kooperatifi. Kadro, 1 (9), 11-8.

Tör, V. N. (1933a). Bizde Hususi Teşebbüsün Zaferi. Kadro, 2 (13), 10-6.

Tör, V. N. (1933b). Ziraat Siyasetimizde Liberalizmden Devletçiliğe. Kadro, 2 (19), 17-22.

Tör, V. N. (1933c). Devletçi Bir Ziraat Siyasetinin Ana Prensipleri. Kadro, 2 (20), 12-9. 
TöR, V. N. (1934). Köylü Kazanmalıdır. Kadro, 3 (33), 11-5.

Türkeş, M. (1998). The Ideology of the Kadro [Cadre] Movement: A Patriotic Leftist Movement in Turkey. Middle Eastern Studies, 34 (4), 92-119.

Türkeş, M. (1999). Uluşu Sol Bir Akım: Kadro Hareketi (1932-1934). Ankara: İmge Kitabevi.

WagenfüHR, R. (1933). Die Industriewirtschaft. Berlin: Reimar Hobbing.

WallersteIn, I. (1974). The Modern World-System: Capitalist Agriculture and the Origins of the European World-Economy in the Sixteenth Century. New York: Academic Press.

YANARDAĞ, M. (2008). Türk SiyasalYaşammnda Kadro Hareketi. İstanbul: Siyah Beyaz. YILDIRIR-Kocabaș, Ö. (2010). Türkiye'de Tarmsal Kooperatifçilik Düşüncesinin Gelişsimi. İstanbul: Libra.

ZÜRCHER, E. J. (2004). Turkey: A Modern History. New York: I. B. Tauris. 